\title{
STRAIN- AND SPECIES-SPECIFIC DISTRIBUTION OF THE STREPTOMYCIN GENE CLUSTER AND kan-RELATED SEQUENCES IN STREPTOMYCES GRISEUS
}

\author{
Kunimoto Hotta and Jun Ishikawa \\ Department of Antibiotics, National Institute of Health, \\ 2-10-35 Kamiosaki, Shinagawa-ku, Tokyo 141, Japan
}

(Received for publication September 29, 1987)

\begin{abstract}
The streptomycin (SM) gene cluster was investigated for its distribution in streptomycetes by Southern hybridization using nick-translated DNA probes, which were isolated from the SM-6-phosphotransferase (SPH) and amidinotransferase (ADT) regions of the SM gene cluster of Streptomyces griseus SS-1198. Bgl II-digested genomic DNAs from SM-producing strains of $S$. griseus yielded the same size fragment $(7.0 \mathrm{~kb})$ which hybridized to both the SPH and ADT probes as expected from the restriction endonuclease cleavage map of the SM gene cluster. By contrast, no genomic DNA fragments from heterologous Streptomyces strains hybridized to the probes. Thus, only SM-producing strains of S. griseus possess the highly homologous SM gene cluster.

Similarly, distribution of DNA sequences homologous to the kanamycin (KM)-resistance determinant ( $k a n)$ from a KM-resistant regenerant of S. griseus SS-1198 protoplasts was also examined. Using the kan gene fragment as the probe it was revealed that the kan-related sequences are present in all the strains of $S$. griseus tested, irrespective of the type of antibiotics they produce. However, no hybridization to the kan gene probe (KAN) was observed with DNA digests derived from other Streptomyces species.
\end{abstract}

It is well recognized that antibiotic production by actinomycetes is not species-specific but strainspecific. However, little is known concerning the biochemical and genetic basis for the strain specificity of antibiotic production in spite of numerous studies on antibiotic biosynthesis and its regulation. We have shown that Streptomyces strains which produce aminoglycoside (AG) antibiotics have individual AG-resistance patterns correlated with the type of antibiotics they produce ${ }^{1,2)}$. In addition to this biochemical relationship, the genetic linkage between antibiotic biosynthetic genes and antibiotic-resistance genes has also been demonstrated in various antibiotic producers ${ }^{3 \sim 8)}$. Consequently, it was of particular interest to determine whether the strain-specific production of antibiotics was associated with a localized distribution or expression of the relevant antibiotic gene cluster in antibioticproducing strains.

Streptomyces griseus includes strains that produce various types of antibiotics such as streptomycin (SM), holomycin and grisein. Since high DNA homologies have been demonstrated among $S$. griseus strains ${ }^{9)}$, it was of interest to establish the genetic basis associated with the strain-specific production of antibiotics in S. griseus. In the SM-producing strains of this species, a gene cluster involving SM-biosynthetic genes and SM-resistance gene has been cloned and well characterized by different laboratories ${ }^{3,10 \sim 15)}$. We have also cloned a gene segment $(3.8 \mathrm{~kb} S p h \mathrm{I})$ directing SMresistance from an SM-producing soil-isolate of S. griseus $^{18)}$. Interestingly, the cloned segment was found to be identical with the region covering SM-resistance and amidinotransferase determinants of the known SM gene cluster in terms of size and restriction site. This fact led us to a hypothesis that distribution of homologous SM gene clusters might be responsible for the strain-specific produc- 
tion of SM in S. griseus. In order to establish this point, we performed Southern hybridization between gene segments located in the SM gene cluster and genomic DNA digests of SM producers as well as nonproducers.

Of further interest to us was the finding that kanamycin (KM)-hyper-resistant clones emerged following protoplast regeneration of a streptomycin-producing strain of S. griseus $^{\left.\mathbf{1 0}^{8}\right)}$ in which no KMresistance had been reported previously. Characterization of the cloned KM-resistance determinant (kan) revealed that a cryptic gene $\left(\mathrm{kan}^{\circ}\right)$ had mutated to kan directing the synthesis of an aminoglycoside acetyltransferase, $\operatorname{AAC}(3)^{17)}$. This dramatic change in antibiotic-resistance seemed to be so unique that we were interested in the distribution of kan-related sequences in Streptomyces. Therefore, Southern hybridization experiments were carried out to establish whether kan exhibited any homology with genomic DNA from other S. griseus strains and other AAC(3)-producing streptomycetes.

In this report we reveal that the SM gene cluster is homologous and specifically distributed among SM-producing strains of S. griseus and that the distribution of homologous sequences to kan appears to be limited to $S$. griseus strains regardless of the types of antibiotics they produce.

\section{Materials and Methods}

Strains Used

S. griseus strains which produce SM or other antibiotics, SM-producing strains of Streptomyces bikiniensis and Streptomyces sp., and other Streptomyces species which produce aminoglycoside antibiotics are listed in Table 1 .

Table 1. Strains used.

\begin{tabular}{|c|c|c|c|c|}
\hline Species & Strains & Antibiotics & Remarks & refs \\
\hline Streptomyces griseus & SS-1198 & Streptomycin & Sapporo, Japan & 16 \\
\hline S. griseus & $\mathrm{SS}-1254^{\mathrm{a}}$ & Streptomycin & Tenjin Island, Japan & This work \\
\hline S. griseus & ISP 5236 & Streptomycin & Rutgers Univ. & 9 \\
\hline S. griseus & HUT6037 & Streptomycin & Hiroshima Univ. & 28 \\
\hline S. griseus & N2-3-11 & Streptomycin & Kaken, Japan & 22 \\
\hline S. griseus & NIHJ 018 & Grisein & NIH Japan & This work \\
\hline S. griseus & NIHJ 060 & Grisein & NIH Japan & This work \\
\hline S.griseus & SS-1429a & Holomycin & SM-resistance & This work \\
\hline S. griseus & MH541-f'-F3 & Holomycin & IMC & This work \\
\hline S. griseus & MH885-SF1 & Chromomycin & IMC & This work \\
\hline S.griseus & MH324-22-F9 & Cycloheximide & IMC & This work \\
\hline S. bikiniensis & ISP 5581 & Streptomycin & SM-6-phosphotransferase & 22,29 \\
\hline Streptomyces sp. & SS-1696 & Streptomycin & Gray color surface & This work \\
\hline Streptomyces sp. & SS +1740 & Streptomycin & Gray color surface & This work \\
\hline S. fradiae & ISP 5063 & Neomycin & $\mathrm{APH}\left(3^{\prime}\right), \mathrm{AAC}\left(3^{3}\right)$ & $2,30,31$ \\
\hline S. kasugaensis & $\mathrm{MB} 273$ & Kasugamycin & $\mathrm{AAC}(3)-\mathrm{I}$ (unpublished) & 20 \\
\hline S. lavendulae & SS-1364 & Neomycin & $\mathrm{APH}\left(3^{\prime}\right), \mathrm{AAC} ?$ & 2 \\
\hline S. lavendulae & SS-1365 & Ribostamycin & $\mathrm{APH}\left(3^{\prime}\right), \mathrm{AAC} ?$ & 2 \\
\hline S. tenebrarius & ISP 5477 & Tobramycin & SM-6-phosphotransferase & 32 \\
\hline S. tenjimariensis & SS-939 & Istamycin & & 33 \\
\hline S. lividans & TK21 & & & 34 \\
\hline
\end{tabular}

a Taxonomic properties fell into those of S. griseus (data not shown).

IMC: Institute of Microbial Chemistry. 
Fig. 1. Probes for detection of the streptomycin gene cluster and kan-related gene.

(A)

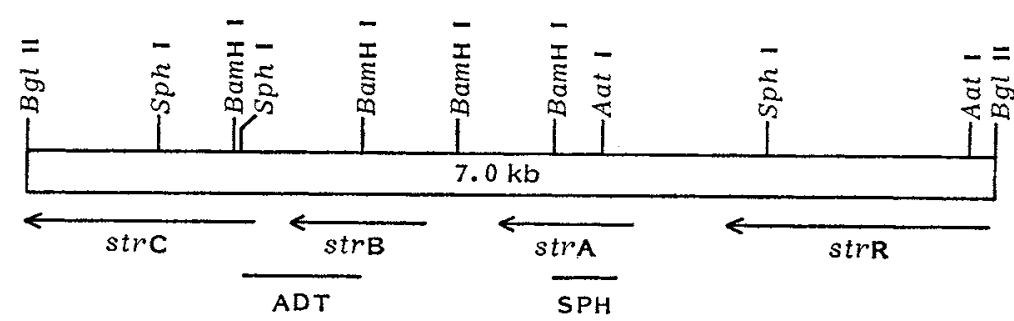

(B)

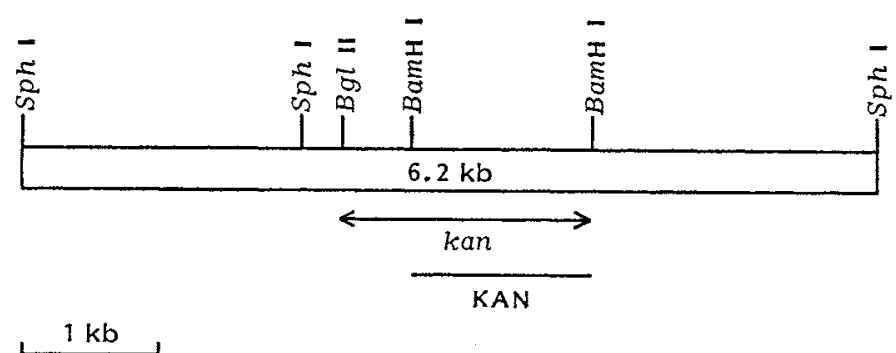

(A) Streptomycin gene cluster (7.0 kb Bgl II fragment) and ADT and SPH probes.

(B) Genomic DNA segment (6.2 kb Sph I fragment) containing kan region and KAN probe.

\section{Preparation of DNA}

Total DNA was isolated from Streptomyces strains as previously described ${ }^{18)}$. DNA fragments used as probes for the SM gene cluster and the kan gene were isolated from the plasmids pANT1 and pANT3 -1, respectively, by the method of GIRVITZ et al. ${ }^{18)}$ after digestion with appropriate restriction endonucleases and separation by agarose gel-electrophoresis. The 0.4-kb $S a l$ I and $0.9 \mathrm{~kb} \mathrm{BamH} \mathrm{I-}$ $S p h$ I fragments corresponding to the SM-6-phosphotransferase (SPH) and amidinotransferase (ADT) determinants, respectively, isolated from pANT1 were used as the SPH and ADT probes. The 1.3-kb BamH I fragment (pANT3-1) was used as the KAN probe (Fig. 1). Radiolabeled fragments (1 $2 \times$ $10^{8} \mathrm{cpm} / \mu \mathrm{g}$ ) were obtained with $\left[\alpha^{-32} \mathrm{P}\right] \mathrm{dCTP}$ using a nick translation kit (Amersham).

\section{Southern Blot Hybridization}

Total DNA was digested completely with $B a m \mathrm{H}$ I or $B g l$ II and the fragments were separated by electrophoresis using $0.8 \%$ agarose in $1 \times \mathrm{TAE}$ buffer. DNA fragments were denatured with $0.5 \mathrm{~N}$ $\mathrm{NaOH}-1.5 \mathrm{M} \mathrm{NaCl}$, neutralized with $0.5 \mathrm{M}$ Tris- $\mathrm{HCl}(\mathrm{pH} 8.0$ ) and transferred to a nitrocellulose filter (BA85, $0.45 \mu \mathrm{m}$; SCHLEICHER and SCHUELL) with $10 \times$ SSC; the filter was then air-dried and baked at $80^{\circ} \mathrm{C}$ for 2 hours as described by SouTHERN ${ }^{18)}$. Prehybridization was performed overnight at 55 $65^{\circ} \mathrm{C}$ in $6 \times \mathrm{SET}(0.9 \mathrm{M} \mathrm{NaCl}, 12 \mathrm{~mm}$ EDTA and $180 \mathrm{~mm}$ Tris- $\mathrm{HCl}, \mathrm{pH} 8.0), 10 \times$ DeNHARDT's solution, $0.1 \% \mathrm{SDS}, 100 \mu \mathrm{g} / \mathrm{ml}$ of sonicated and denatured calf thymus DNA; hybridization was carried out under the same conditions for 45 hours in fresh using $5 \sim 10 \mathrm{ng} / \mathrm{ml}$ of a probe. After hybridization the filter was washed 3 times with $2 \times \operatorname{SSC}(200 \mathrm{ml})$ at increasing temperatures $\left(60,65\right.$ and $\left.75^{\circ} \mathrm{C}\right)$ for 30 minutes each. Autoradiography was carried out by exposing X-ray film (Fuji RX) to the filter overnight at $-80^{\circ} \mathrm{C}$.

\section{Results}

\section{Distribution of the SM Gene Cluster}

In order to examine the distribution of the SM gene cluster in Streptomyces strains, we carried 
out hybridization experiments using $B g l \mathrm{II}$-digested genomic DNA with the SPH $(0.4 \mathrm{~kb} S a l \mathrm{I})$ and ADT $(0.9 \mathrm{~kb}$ Bam H I - Sph I) gene probes. If the SM gene cluster was homologous in Streptomyces strains, it would be expected that $B g l$ II-digests of genomic DNA would possess a 7.0-kb hybridizing fragment (Fig. 1). Indeed, $B g l$ II-digests from all of the SM-producing strains (left 6 lanes) of S. griseus contained the same sized fragment $(7.0 \mathrm{~kb})$ which hybridized strongly to both the $\mathrm{SPH}$ and $\mathrm{ADT}$ probes (Fig. 2B). It is of interest that these strains included isolates collected from soils in the U.S.A. and Japan (Table 1). Hybridization was so intense that the radiolabeled probes could not be removed from the filter by washing with $2 \times$ $\mathrm{SSC}$ at $90^{\circ} \mathrm{C}$ (30 minutes); dissociation necessitated the treatment of the filter in boiling water for 15 minutes. These results clearly indicate that there is a high degree of homology between the probes and the target sequences. In contrast, DNA digests from $S$. griseus strains (right 6 lanes) that produce grisein, holomycin, cycloheximide or chromomycin, or from different Streptomyces species failed to hybridize to the probes. Interestingly, digests from other SM-producing organisms (e.g. S. bikiniensis ISP 5581 and Streptomyces sp. SS-1696 and SS-1740) also failed to hybridize to the SPH probe (data not shown). Furthermore, no homologous sequence (to $\mathrm{SPH}$ ) was seen in the tobramycin-producing Streptomyces tenebrarius ISP 5477 or holomycinproducing S. griseus SS-1429 digests, although the former organism is known to produce an SM-6-phosphotransferase ${ }^{20)}$ and the latter is resistant to $\mathrm{SM}(100 \mu \mathrm{g} / \mathrm{ml})$. Thus, it appears that the homologous SM gene cluster of $S$. griseus is specifically present in SM-producing strains of S. griseus.

\section{Distribution of Genes Homologous to the kan Gene}

The filter previously used for the hybridization experiment with $\mathrm{Bgl}$ II-digested genomic DNA was subsequently subjected to Southern analysis with the KAN probe (Fig. 2C). Large fragments $(20 \sim 23 \mathrm{~kb})$ hybridizing to the probe were observed in all of the SM-producing strains of S. griseus (left 6 lanes). Unexpectedly, hybridization signals were also observed in the other $S$. griseus strains
Fig. 2. Hybridization between $B g l$ II-digested genomic DNA and probes for streptomycin gene cluster and $k a n$-related genes.

(A)

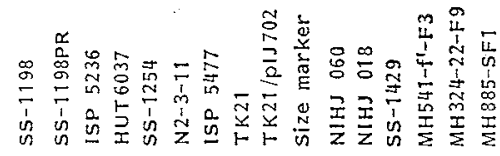

(B)

C)

(A) Agarose gel electrophoresis of $B g l \mathrm{II}$ digested genomic DNA. Size marker: Mixture of Hind III-digested $2 \mathrm{DNA}$ and Hae III-digested X174DNA was used.

(B) Hybridization with ADT and SPH probes. Hybridization between $\mathrm{Bgl}$ II-digested DNA fragments and SPH probe was erased by washing the An boiling water and then hybridization with ADT probe was petformed. Exactly the same hybridization signals were obtained.

(C) Hybridization with KAN probe was carried out by using the filter used for hybridization with SPH and ADT probes (B). 
(right 6 lanes) which produce different antibiotics. However, no hybridization signals were detected with the DNA digests from the other Streptomyces sp. tested.

Hybridization analysis using the BamH Idigests of genomic DNAs and the KAN probe provided more conclusive results. Thus, all of the SM-producing $S$. griseus strains examined (left 4 lanes) except SS-1254 contained the same sized fragment $(1.3 \mathrm{~kb})$ which hybridized to the KAN probe. In comparison, the BamH I-digest of genomic DNA from the latter strain possessed a larger hybridizable fragment, about $10 \mathrm{~kb}$ (5th lane from the left), although its DNA finger print and the SM gene cluster were indistinguishable from those of the other SM-producing strains of $S$. griseus. The digests from the other $S$. griseus strains (SS-1429, NIHJ 060 and NIHJ 018) also contained hybridizing fragments $(2.8,1.3$ and
Fig. 3. Hybridization between BamH I-digested genomic DNA and KAN probe.

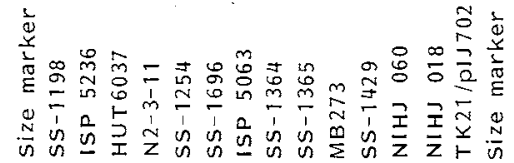

(A)

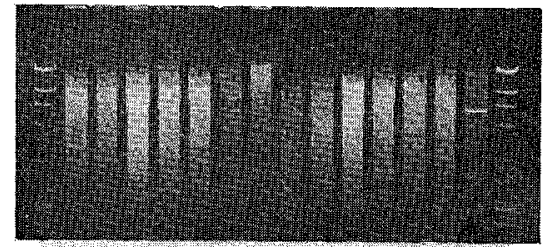

(B)

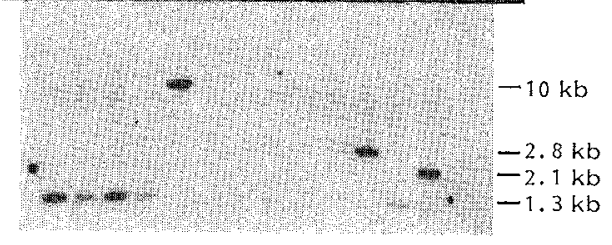

(A) Agarose gel electrophoresis of BamH Idigested genomic DNA. Size marker: Same as Fig. 2(A).

(B) Hybridization with KAN probe.

Table 2. Summary of hybridization between genomic DNA digests and SPH, ADT and KAN probes.

\begin{tabular}{|c|c|c|c|c|c|}
\hline \multirow{3}{*}{ Species } & \multirow{3}{*}{ Strains } & \multirow{3}{*}{ Antibiotics } & \multicolumn{3}{|c|}{ Hybridization } \\
\hline & & & \multirow{2}{*}{$\frac{\text { SPH and ADT }}{\begin{array}{c}B g l \text { II- } \\
\text { digest }(\mathrm{kb})\end{array}}$} & \multicolumn{2}{|c|}{ KAN } \\
\hline & & & & $\begin{array}{c}\text { BamH I- } \\
\text { digest (kb) }\end{array}$ & $\begin{array}{c}B g l \mathrm{II}- \\
\text { digest }(\mathrm{kb})\end{array}$ \\
\hline S. griseus & SS-1198 & Streptomycin & 7.0 & 1.3 & $20 \sim 23$ \\
\hline S. griseus & ISP 5236 & Streptomycin & 7.0 & 1.3 & $20 \sim 23$ \\
\hline S. griseus & HUT6037 & Streptomycin & 7.0 & 1.3 & $20 \sim 23$ \\
\hline$S$. griseus & N2-3-11 & Streptomycin & 7.0 & 1.3 & $20 \sim 23$ \\
\hline S. griseus & SS-1254 & Streptomycin & 7.0 & 10 & $20 \sim 23$ \\
\hline S. griseus & NIHJ 018 & Grisein & -- & 2.1 & $20 \sim 23$ \\
\hline S. griseus & NIHJ 060 & Grisein & - & 1.3 & $20 \sim 23$ \\
\hline S. griseus & SS-1429 & Holomycin & - & 2.8 & $20 \sim 23$ \\
\hline S. griseus & MH541-f'-F3 & Holomycin & - & $\mathrm{nt}$ & $20 \sim 23$ \\
\hline S. griseus & MH885-SF1 & Chromomycin & - & $\mathrm{nt}$ & $20 \sim 23$ \\
\hline S. griseus & MH324-22-F9 & Cycloheximide & - & $\mathrm{nt}$ & $20 \sim 23$ \\
\hline S. bikiniensis & ISP 5581 & Streptomycin & - & - & - \\
\hline Streptomyces sp. & SS-1696 & Streptomycin & - & - & 一 \\
\hline Streptomyces sp. & SS-1740 & Streptomycin & - & - & - \\
\hline S. fradiae & ISP 5063 & Neomycin & - & - & - \\
\hline S. kasugaensis & MB273 & Kasugamycin & - & - & - \\
\hline S. lavendulae & SS-1364 & Neomycin & - & - & 一 \\
\hline S. lavendulae & SS-1365 & Ribostamycin & - & - & 一 \\
\hline S. tenebrarius & ISP 5477 & Tobramycin & - & - & - \\
\hline S. tenjimariensis & SS-939 & Istamycin & - & - & 一 \\
\hline S. lividans & TK21 & & - & - & - \\
\hline
\end{tabular}

nt: Not tested. 
$2.1 \mathrm{~kb}$, respectively). However, no hybridization signals were detected in the other Streptomyces species irrespective of the type of aminoglycoside antibiotic and AAC produced. Thus, it appears reasonable to conclude that the kan-related genes are specifically associated with $S$. griseus species, as summarized in Table 2.

\section{Discussion}

As described, hybridization studies have revealed that a SM gene cluster, which is highly homologous, is specifically distributed in SM-producing strains of $S$. griseus. Further, DNA sequences homologous to this gene cluster in heterologous Streptomyces strains including SM-producing $S$. bikiniensis appear to be absent. In this context, DisTLER et al. ${ }^{13)}$ have shown that a genomic digest from a dihydro-SM-producing strain of Streptomyces glaucescens did not hybridize to the SPH gene of an SM-producing strain of S. griseus. It should also be noted that a gene segment, cloned from SMproducing $S$. bikiniensis IFO 13350 (derived from $S$. bikiniensis ISP 5235) and directing the biosynthesis of the $N$-methyl-L-glucosamine moiety of SM, possesses a region that overlaps part of the SM gene cluster of $S$. griseus $^{21}$. Such homology may be attributable to the fact that this strain is accidentally derived from S. griseus ISP 5236 and had been improperly designated as an S. bikiniensis strain $^{22,23)}$. In support of this assignment, OKANISHI et al. have demonstrated that there is a $100 \%$ DNA-DNA homology between the strains ISP 5235 and ISP 5236 ${ }^{\circ)}$. Thus, it is obvious that the strain specific distribution of a SM gene cluster is associated with the strain specific production of SM in S. griseus. It would be of interest to establish whether the SM-biosynthetic genes of SM-producing strains of other Streptomyces species are clustered or not.

Genes ( $a f s \mathrm{~A}$ and $a f s \mathrm{~B}$ ) specifying A-factor have been reported to regulate positively SM production in $S$. griseus ${ }^{24,25)}$. These regulatory genes may represent other genetic determinants associated with SM production. However, based on hybridization studies, distribution of genes homologous to these A-factor-related genes is not limited to SM-producing strains of S. griseus. Therefore, the SM gene cluster can be regarded as the marker genotype for SM production in S. griseus. In this regard, the antibiotic biosynthetic gene clusters described for several other antibiotic-producing strains of actinomycetes do not possess the same limited distribution. It has been shown that the "early" gene(s) (act I) of the actinorhodin gene cluster are widely distributed among heterologous polyketideproducing Streptomyces species ${ }^{26)}$. Likewise, DNA fragments hybridizing to the undecylnorprodigiosin: $S$-Adenosylmethionine $O$-methyltransferase gene involved in the biosynthesis of undecylnorprodigiosin $^{27)}$ were also reported to be distributed widely and thus are not confined to specific strains or species that produce the antibiotic. Based on these reports it appears that the SM genecluster of $S$. griseus is unique.

Unexpectedly, all of the $S$. griseus strains tested had sequences homologous to the kan gene directing an $\mathrm{AAC}(3)$. In contrast, no heterologous species examined possessed hybridizing DNA fragments regardless of their synthesis of AAC (3). It should be noted, in the case of $S$. griseus strains, that kan-related sequences represent the first case of species-specific DNA sequence in Streptomyces. This finding suggests some specific role(s) for the kan-related gene(s) in the life of S. griseus, although no information is available about their function at present.

The species-specific distribution of kan-related sequence may have taxonomic importance. For instance, strain SS-1429 had not been subjected to taxonomic identification until the sequence homologous to kan was discovered. A detailed study revealed that the strain SS-1429 belonged taxonomically to $S$. griseus (data not shown). Thus, kan-related sequences may be a useful genotypic marker for identification of $S$. griseus strains.

\section{Acknowledgments}

We are grateful to Dr. M. HAMADA for S. griseus MH541-f'-F3, MH885-SF1 and MH324-22-F9, Prof. O. NIMI for S. griseus HUT6037, and Kaken Pharmaceutical Co., Ltd., for S. griseus N2-3-11. We also express our deep thanks to the late Prof. H. Umezawa, Prof. Y. Okami, Prof. Y. Koyama, Dr. S. Mizuno and Dr. M. 
YAGISAWA for their encouragement. This work was partially supported by grants from Human Science Foundation and Sapporo Life Science Promoting Foundation.

\section{References}

1) HotTa, K.; A. Takahashi, N. Saito, Y. Okami \& H. Umezawa: Multiple resistance to aminoglycoside antibiotics in actinomycetes. J. Antibiotics 36: 1748 1754, 1983

2) HotTA, K.; A. TAKAHASHI, Y. OKAmI \& H. UmeZAWA: Relationship between antibiotic resistance and antibiotic productivity in actinomycetes which produce aminoglycoside antibiotics. J. Antibiotics 36: $1789 \sim 1791,1983$

3) Ohnuki, T.; T. Imanaka \& S. AIBa: Self-cloning in Streptomyces griseus of an str gene cluster for streptomycin biosynthesis and streptomycin resistance. J. Bacteriol. 164:85 94, 1985

4) Chater, K. F. \& C. J. BRuton: Resistance, regulatory and production genes for the antibiotic methylenomycin are clustered. EMBO J. 4: 1883 1892, 1985

5) Malpartida, F. \& D. A. Hopwood: Molecular cloning of the whole biosynthetic pathway of a Streptomyces antibiotic and its expression in a heterologous host. Nature 309: 462 464, 1984

6) Stanzak, R.; P. Matsushima, R. H. Baltz \& R. N. RaO: Cloning and expression in Streptomyces lividans of clustered erythromycin biosynthesis genes from Streptomyces erythreus. Biotechnology 4: 229 232, 1986

7) Murakami, T.; H. Anzai, S. Imai, A. Satoh, K. Nagaoka \& C. J. Thompson: The bialaphos biosynthetic genes of Streptomyces hygroscopicus: Molecular cloning and characterization of the gene cluster. Mol. Gen. Genet. 205: 42 50, 1986

8) Motamedi, H. \& C. R. Hutchinson: Cloning and heterologous expression of a gene cluster for the biosynthesis of tetracenomycin $\mathrm{C}$, the anthracycline antitumor antibiotic of Streptomyces glaucescens. Proc. Natl. Acad. Sci. U.S.A. 84: 4445 4449, 1987

9) Okanishi, M.; H. Akagawa \& H. Umezawa: An evaluation of taxonomic criteria in streptomycetes on the basis of deoxyribonucleic acid homology. J. Gen. Microbiol. 72: 49 58, 1972

10) Tohyama, H.; T. Shigyo \& Y. Okami: Cloning of streptomycin resistance gene from a streptomycin producing streptomycete. J. Antibiotics 37: 1736 1737, 1984

11) Tohyama, H.; Y. OKami \& H. Umezawa: Nucleotide sequence of the streptomycin phosphotransferase and amidinotransferase genes from Streptomyces griseus. Nucleic Acids Res. 15: 1819 1833, 1987

12) Distler, J.; K. Mansouri \& W. Piepersberg: Streptomycin biosynthesis in Streptomyces griseus. II. Adjacent genomic location of biosynthetic genes and one of two streptomycin resistance genes. FEMS Microbiol. Lett. 30: 151 154, 1985

13) Distler, J.; C. Braun, A. Ebert \& W. Piepersberg: Gene cluster for streptomycin biosynthesis in Streptomyces griseus: Analysis of a central region including the major resistance gene. Mol. Gen. Genet. 208: 204 210, 1987

14) Vallins, W. J.S. \& S. Baumberg: Cloning of a DNA fragment from Streptomyces griseus which directs streptomycin phosphotransferase activity. J. Gen. Microbiol. 131: 1657 1669, 1985

15) Distler, J.; A. Ebert, K. Pissowotzki, M. Stockmann \& W. Piepersberg: Gene cluster for streptomycin biosynthesis in Streptomyces griseus: Nucleotide sequence of three genes and analysis of transcriptional activity. Nucleic Acids Res. 15: $8041 \sim 8056,1987$

16) Hotta, K.; J. Ishikawa, M. Ichihara, H. Naganawa \& S. Mizuno: Mechanism of increased kanamycin-resistance generated by protoplast regeneration of Streptomyces griseus. I. Cloning of a gene segment directing a high level of an aminoglycoside 3- $N$-acetyltransferase activity. J. Antibiotics $41: 94 \sim 103$, 1988

17) Ishikawa, J.; Y. Koyama, S. Mizuno \& K. Hotra: Mechanism of increased kanamycin-resistance generated by protoplast regeneration of Streptomyces griseus. II. Mutational gene alteration and gene amplification. J. Antibiotics 41: 104 112, 1988

18) Girvitz, S. C.; S. Bacchetti, A. J. Rainbow \& F. L. Graham: A rapid and efficient procedure for the purification of DNA from agarose gels. Anal. Biochem. 106: 492 496, 1980

19) Southern, E. M.: Detection of specific sequences among DNA fragments separated by gel electrophoresis. J. Mol. Biol. 98: 503 517, 1975

20) ToYama, H.; M. OKanishi \& H. Umezawa: Physical characterization of plasmids from Streptomyces kasugaensis MB273. Plasmid 5: 306 312, 1981

21) Kumada, Y.; S. Horinouchi, T. UOZUMI \& T. Beppu: Cloning of a streptomycin-production gene directing synthesis of $N$-methyl-L-glucosamine. Gene 42: 221 224, 1986 
22) Shirling, E. B. \& D. Gottlieb: Cooperative description of type strains of Streptomyces. V. Additional descriptions. Int. J. Syst. Bacteriol. 22: $265 \sim 394,1972$

23) List of cultures 1984,7 th Ed., p. 95, Institute for Fermentation, Osaka, 1984

24) Horinouchi, S.; Y. Kumada \& T. Beppu: Unstable genetic determinant of A-factor biosynthesis in streptomycin-producing organisms: Cloning and characterization. J. Bacteriol. 158: 481 487, 1984

25) Horinouchi, S.; H. Suzuki \& T. BePPU: Nucleotide sequence of afs B, a pleiotropic gene involved in secondary metabolism in Streptomyces coelicolor A3(2) and 'Streptomyces lividans'. J. Bacteriol. 168: $257 \sim 269,1986$

26) Malpartida, F.; S. E. Hallam, H. M. Kieser, H. Motamedi, C. R. Hutchinson, M. J. Butler, D. A. Sugden, M. Warren, C. McKillop, C. R. Bailey, G. O. Humphreys \& D. A. Hopwood: Homology between Streptomyces genes coding for synthesis of different polyketides used to clone antibiotic biosynthetic genes. Nature 325: $818 \sim 821,1987$

27) Feitelson, J. S.; F. Malpartida \& D. A. Hopwood: Genetic and biochemical characterization of the red gene cluster of Streptomyces coelicolor A3(2). J. Gen. Microbiol. 131: 2431 2441, 1985

28) Shinkawa, H.; M. Sugiyama, O. Nimi \& R. Nomi: Molecular cloning and expression in Streptomyces lividans of a streptomycin 6-phosphotransferase gene from a streptomycin-producing microorganism. FEBS Lett. 181: 385 389, 1985

29) Walker, J. B. \& M. Skorvaga: Phosphorylation of streptomycin and dihydrostreptomycin by Streptomyces. J. Biol. Chem. 248: 2435 2440, 1973

30) Davies, J.; C. Houk, M. Yagisawa \& T. J. White: Occurrence and function of aminoglycoside-modifying enzymes. In Genetics of Industrial Microorganisms. Eds., O. K. SEBEK \& A. I. LAskIN, pp. 166 169, American Society for Microbiology, Washington, D.C., 1979

31) Thompson, C. J.; R. H. Skinner, J. Thompson, J. M. Ward, D. A. Hopwood \& E. Cundliffe: Biochemical characterization of resistance determinants cloned from antibiotic-producing streptomycetes. J. Bacteriol. 151: 678 685, 1982

32) Yamamoto, H.; K. HotTA, Y. OKami \& H. UmezaWA: Mechanism of resistance to aminoglycoside antibiotics in nebramycin-producing Streptomyces tenebrarius. J. Antibiotics 35: 1020 1025, 1982

33). Shigyo, T.; K. Hotta, Y. Okami \& H. UMeZAWA: Plasmid variability in the istamycin producing strains of Streptomyces tenjimariensis. J. Antibiotics 37: 635 640, 1984

34) Hopwood, D. A.; T. Kieser, H. M. Wright \& M. J. BibB: Plasmids, recombination and chromosome mapping in Streptomyces lividans 66. J. Gen. Microbiol. 129: $2257 \sim 2269,1983$ 